\title{
The development of learning song-integrated module based on flipped learning model to improve self-regulated learning and cognitive learning outcome of junior high school students
}

\author{
A. Andreas ${ }^{1,{ }^{*}, \text { Risya Pramana Situmorang }}{ }^{2}$, Susanti Pudji Hastuti ${ }^{3}$ \\ Biology Education Department, Faculty of Biology, Universitas Kristen Satya Wacana, Indonesia \\ ${ }^{1}$ andreasdreas84@gmail.com *, 2. pramana_risya@yahoo.com, ${ }^{3}$ susanti012@gmail.com \\ * Corresponding author
}

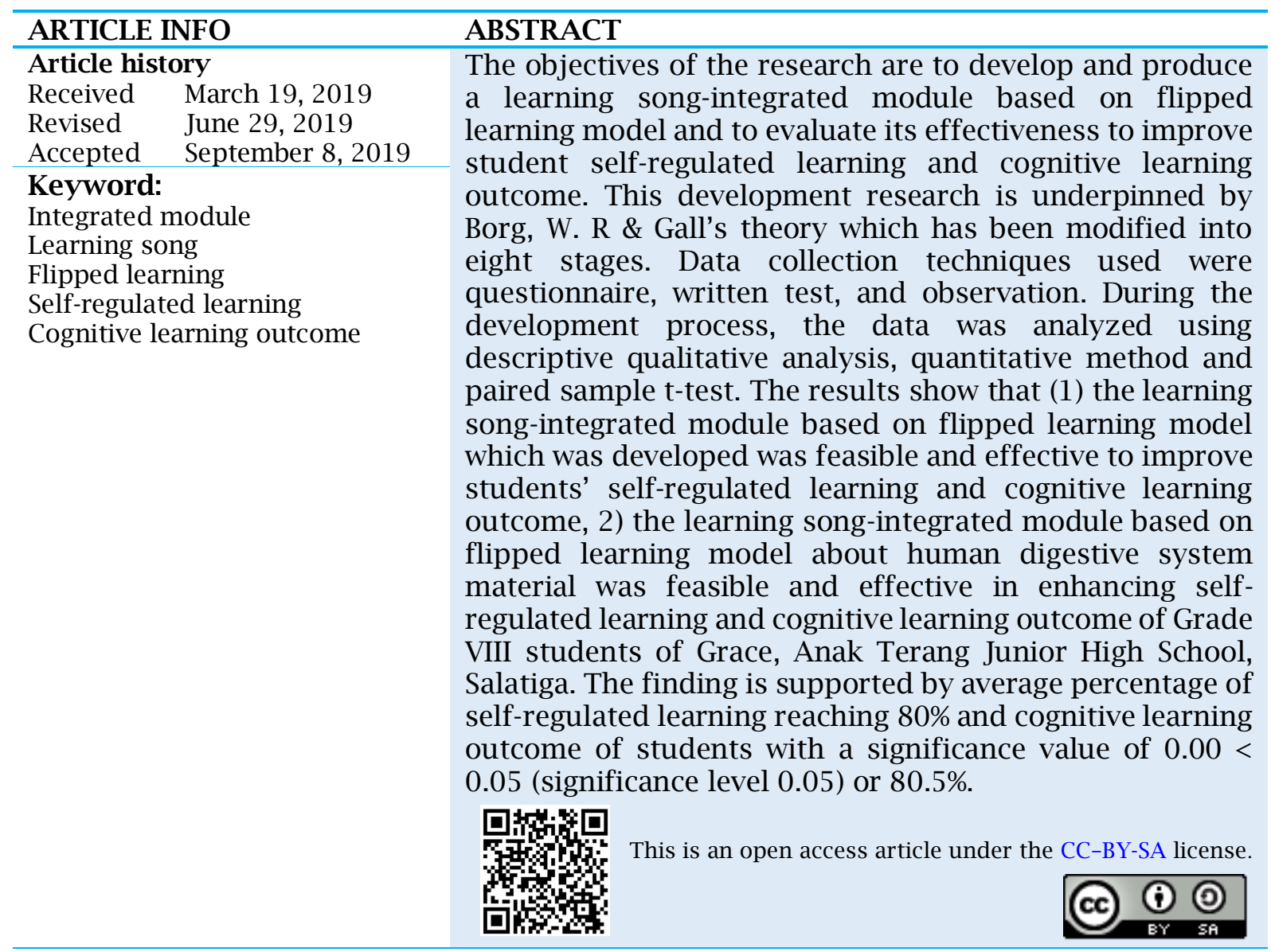

\section{Introduction}

The rapid development of science and technology has encouraged innovation in using technology to improve the learning process. As stated in the 2016 National Education Ministerial Regulation (Permendikbud) number 22, teachers who can develop students' cognitive ability and attitude towards active exploration of selfcompetence in learning are required in the teaching and learning process. According to Hui and Umar (2011), one of the important abilities of students in managing themselves is self-regulated learning (SRL). Students who are able to manage themselves will also be able to analyze learning tasks, set goals, plan, and make decisions about how learning will be carried out. To achieve learning which promotes self-regulated learning, it demands teacher's understanding and skills to 
accommodate and implement such learning in class. Self-regulated learning can prepare students to be qualified human resources that are competent to face global challenges.

The problem that still exists is that the learning process still focuses on cognitive ability without sufficient attention to students' self-regulation skill. The impact of this learning orientation is that it can hinder students' learning retention and ability to transfer knowledge (Zheng, Li, \& Chen, 2016). As a result, students' psychomotor skills and attitude cannot develop fully. It is ironic because ideally education should be able to develop the cognitive, affective and psychomotor aspects (Paas, Renkl, \& Sweller, 2003).

Inadequate

$$
\text { participation }
$$

in

psychomotor activities will affect students' determination in learning (Febriyani, 2013; Ilmi, 2011). Students' internal motivation is an important part of learning that allows students to take action and progress (Harlen \& Crick, 2003; Markova, 2014; Oliveira \& Oliveira, 2013). Self-regulated learning (SRL) ability includes the ability to generate motivation, determination, and selfevaluation. It is important that SRL ability is introduced to students since junior high school. If students are not accustomed to SRL, it is likely to affect their ability to set learning goals, motivate themselves and reflect on their learning outcome.

The interview with the Natural Science teachers of Grade VIII Grace, Anak Terang Junior High School, Salatiga reveals that teachers have never measured the students' self-regulated learning ability specifically. The teachers said that most students still depend on the teachers in learning. The ability of students to learn independently still cannot be seen in the learning process either inside or outside the classroom. In facilitating SRL, a pleasant learning atmosphere should certainly be considered. Building learning interaction is one of the ways to stimulate students' SRL ability in learning. It becomes the teacher's responsibility as a facilitator to improve students' interest in the lesson to attain knowledge optimally. Teachers must understand that conventional teaching methods will not arouse student learning motivation. Wolters, Pintrich, and Karabenick (2005) states that SRL can be done through practice strategies (using repetitive materials and is retentionoriented), process of organizing strategies by managing content information, elaboration strategies (processing information according to one's own understanding), and metacognition monitoring (assessing understanding and progress towards achieving learning goals). Song, Jong, Chang, and Chen (2017); Hamdan, McKnight, McKnight, and Arfstrom (2013) say that one learning model that can promotes interaction and train students in managing their abilities is flipped learning. Johnson (2013) states that flipped learning can be used to improve SRL because this learning model can minimize the number of instructions given to students and maximize the interaction among students. Enfield (2013) also explain that flipped learning can enhance students' creativity, learning outcome and foster students' learning motivation, as well as independent learning ability. This notion is also supported by (Hanif, 2016; Zhang, Du, Yuan, \& Zhang, 2016) who state that the use of flipped classroom model is more effective in improving student SRL than the conventional learning.

The advantages of flipped learning model are the efficient use of class time, more effective learning opportunities for students, one-on-one interaction between students and teacher, student responsibility for learning, multiple learning styles management, and the implications on student learning (Cole \& Kritzer, 2017; Sinaga, 2017). Smith (2013) emphasizes that flipped learning has an impression that it can reduce students' boredom and create interactive learning in each phase of learning. The use of the flipped learning model provides space for students to take an active role in learning.

The 2013 curriculum expects teachers to become facilitators as well as motivators for their students. Therefore, in the teaching and learning process the teachers can apply a variety of methods so that the concept of the material can be understood well. Teachers can use methods which are combined with flipped learning model. One method that teachers can use is learning through song. Learning song is used to reduce boredom during learning process. Songs can be combined with the teaching material in the form of module that is integrated into the phase of flipped learning model to facilitate students' independent learning and maintain students' concentration through simple activities. 
Schellenberg (2006) states that human short-term memory storage capacity is limited to less than seven pieces of information. Information that is never transferred to long-term memory will disappear faster and will be more difficult to recall. Student attention to the lesson can provide a positive effect on the ability to memorize and it is an important factor that determines students' understanding of the material presented (Schellenberg, 2006).

Variations in learning activities that can be done through learning song include yelling, applauding, and singing the song which contains the lyrics about the material that has been learned. Munafifah (2016) explains that singing is loved by all ages, from children to adults. Singing has the potential as fun means to make memorization (retention) easier. Learning song can be used as a way to understand the material effectively and simply. It can be done by teacher either as a facilitator or a motivator.

This research has never been conducted by previous studies. The weakness of the previous studies is in the presentation of the material which did not use specific teaching material related to flipped learning and was not integrated with learning song. Therefore, the research results only demonstrated an increase in self-regulated learning but did not emphasize on the accuracy of the material. This research is different because the end product is a learning song-integrated module that will provide opportunities for students to learn to manage themselves. It is expected that they can understand the content of the material presented optimally.

Therefore, in this way self-regulated learning can be improved by combining flipped learning model and learning song. This study aims to develop and produce a learning song-integrated module based on flipped learning model and to evaluate its effectiveness to improve self-regulated learning and cognitive learning outcome of Grade VIII students of Grace Anak Terang Junior High School, Salatiga, in relation to human digestive system material.

\section{Method}

This study is a research and development. This development research is underpinned by Borg, W. R \& Gall's theory which has been modified into eight stages, namely: introduction study and information collection, planning and design, preparation of learning song-integrated module, product validation I (internal review) by material experts, learning media experts, and composers for learning song media, initial product revision, product validation II (external review) by Natural Science teachers and students. Borg and Gall's model was modified due to the limitation in the number of researchers for dissemination in the experimental test. The modification, however, does not significantly change the research results obtained (Nasution, Hasruddin, \& Gultom, 2018). The limited experimental test was conducted in two stages, namely peer assessment and student assessment by ten Grade VIII students of Grace, Anak Terang Junior High School, Salatiga. The next step was conducting an operational field test/ product effectiveness test by implementing the learning song-integrated module based on flipped learning in the classroom of Grade VIII Grace, Anak Terang Junior High School, Salatiga.

This research was conducted at Anak Terang Junior High School, Salatiga. It was conducted from September to December in the odd semester of the 2018/2019 academic year. The research participants were ten Grade VIII students who were randomly selected.

The research instruments used for collecting data consisted of questionnaire, written test, and observation. The observation focused on the effectiveness of the learning model and the improvement of students' SRL. The questionnaire was used to examine students' response on the implementation of the learning songintegrated module based on flipped learning model. The written test was employed to measure students' cognitive learning outcome. The research and development instruments used were the validation questionnaire for learning songintegrated module from the validation experts, students, observation sheets, test results and interview. The assessment criteria in the product validation questionnaire was in the form of quantitative data. Each answer category becomes a reference for experts in evaluating the products namely module and learning song (Arsyad, 2016).

The validation was carried out by experts in the field of human physiology. The data obtained was analyzed using descriptive quantitative method and then 
described qualitatively using data triangulation techniques. Stages in the data analysis were used to examine the feasibility of the learning song-integrated module and to make a decision for improvement. The four-scale used based on Mardapi (2008) and Akbar (2013) is presented in Table 1 and Table 2.

Table 1. Category of the module assessment score by validators

\begin{tabular}{|c|c|c|}
\hline Interval & Score & Category \\
\hline$X \geq Y$ & A & \\
\hline & D & \\
\hline & $c$ & \\
\hline $\mathrm{X}<\mathrm{Yi}-$ & $\underline{D}$ & $1 \times 0$ \\
\hline \multicolumn{3}{|c|}{$\begin{array}{l}\text { Description : } \\
\text { Yi }=\text { Ideal score average }=(\text { Max ideal score }+ \text { Min ideal } \\
\text { score }) \\
\text { Standard deviation }(\mathrm{Sbi})=1 / 6 \text { (Max ideal score }+ \text { Min } \\
\text { ideal score }) \\
\mathrm{X}=\text { Score } \\
\text { Ideal maximum score }=\Sigma \text { criterion } \times \text { highest score } \\
\text { Ideal minimum score }=\Sigma \text { criterion } \times \text { lowest score }\end{array}$} \\
\hline
\end{tabular}

Table 2. Criteria for module improvement decision making

\begin{tabular}{cll}
\hline Percentage & Qualification & Description \\
\hline $90 \%-100 \%$ & Very good & No revision \\
$75 \%-89 \%$ & Good & No revision \\
$65 \%-74 \%$ & Satisfactory & Revision \\
$55 \%-64 \%$ & $\begin{array}{l}\text { Not good } \\
\text { enough }\end{array}$ & Revision \\
& Less & Revision \\
& satisfactory & \\
\hline
\end{tabular}

\section{Results and Discussion}

\section{Experts' Validation of Material, Module, and Learning Song}

The validation results obtained from biologists about human digestive system material compiled in the module shows an average percentage of $74.32 \%$, meaning that it is valid. Figure 2 present the validation results from material experts. The average percentage of the book design assessment by media and learning design experts is $87.50 \%$ meaning that it is very valid. Data validation results from media and learning design experts are presented in Figure 3.

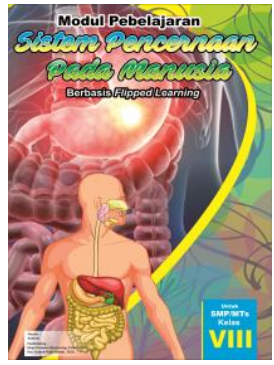

Figure 1. Module cover $n$ material human digestive system
The effectiveness test of the learning song-integrated module based on flipped learning model to increase student selfregulated learning and cognitive learning outcome was conducted using paired samples t-test with the help of SPSS. The effectiveness test is the prerequisite analysis test which includes normality test and homogeneity test. After that, the hypothesis test with paired samples t-test was conducted.

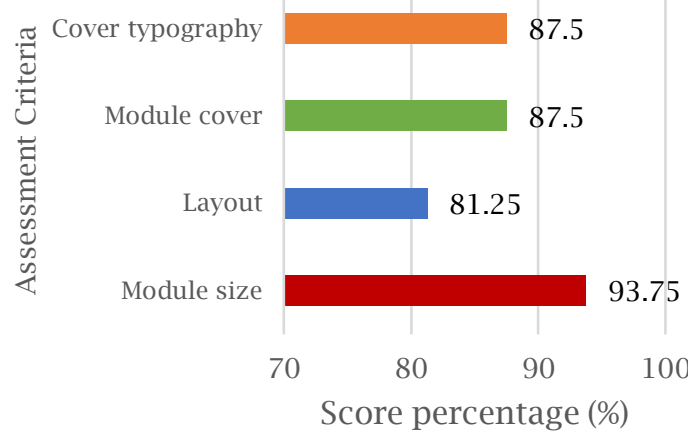

Figure 2. Module validation results from material experts

The results obtained from expert judgment are the parameters used to measure the validity of the learning module. It can be seen from the results that the module belongs to the valid category. It indicates that the module is ready to be implemented in schools. The appropriateness and accuracy of the material were measured using a response questionnaire. After the experts read and understood the contents of the module, the questionnaire was distributed. The practicality of the teaching material is relevant with the target material to achieve (Septiani, Syakbaniah, \& Mufit, 2013).

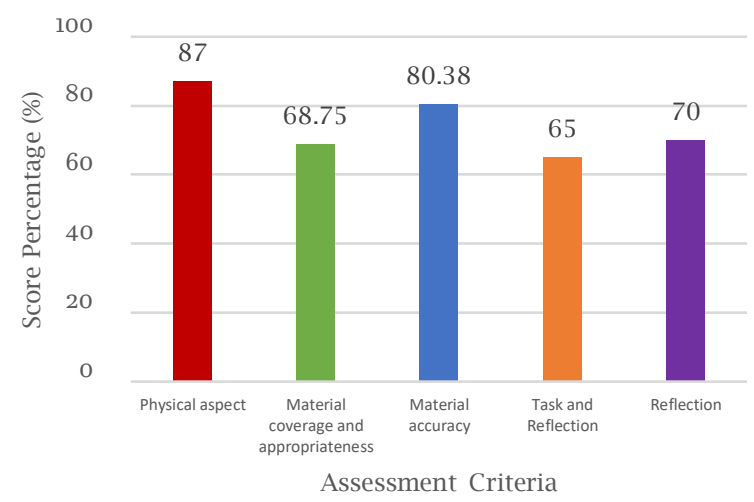

Figure 3. Learning module validation from media experts 
The validation results obtained from music experts, especially in the melody composition arranged in the score illustrate that the average percentage is $94.16 \%$, meaning that it is very valid. A summary of the validation results by experts in learning song is presented in Figure 4.

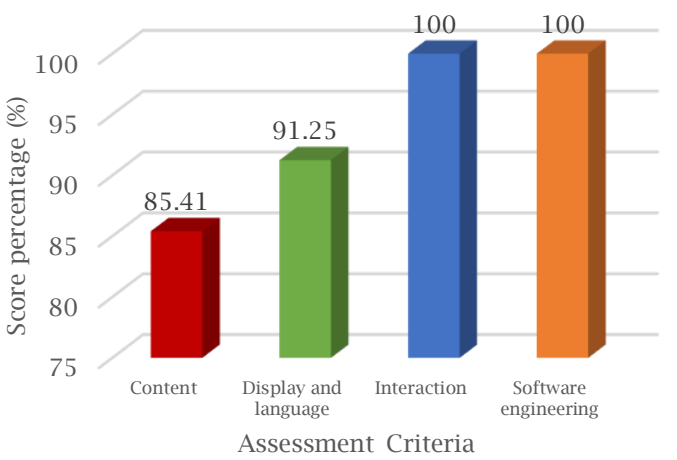

Figure 4. Learning Song Validation from Media Experts

Improvement and revision of the developed module and learning song were based on the recommendation and comments from the validators. The module and learning song produced for learning about human digestive system must meet all criteria so that the material presented is relevant to the learning objectives. It is in line with Asyhar (2012) who states that good learning media is one which is relevant with the learning target, topic, and learning objectives. Recommendation and comments from material, media and learning design experts as validators are presented in Table 3 and Table 4.

Table 3. Comments and recommendation from experts in learning module material

\begin{tabular}{ll}
\multicolumn{1}{c}{$\begin{array}{c}\text { Assessment } \\
\text { criteria }\end{array}$} & \multicolumn{1}{c}{ Recommendation } \\
\hline Physical aspect & 1. $\quad$ Inconsistent font size \\
& $2 . \quad \begin{array}{l}\text { Important terms } \\
\text { should be in italics }\end{array}$ \\
Content/ Material & $\begin{array}{l}\text { More pictures for } \\
\text { elaboration }\end{array}$ \\
Evaluation & $\begin{array}{l}\text { Evaluation questions are } \\
\text { still in LOTS type not HOTS } \\
\text { type }\end{array}$ \\
\hline
\end{tabular}

Based on the observation about the needs of students, it was found that students were capable of learning independently. However, the number of available teaching materials and variations of learning media in school are inadequate. In accommodating student needs, it is necessary to develop teaching materials in the form of module that is integrated with teaching media. Furthermore, based on the analysis of basic competency, the material that has the potential to be developed into a module and learning song media based on flipped learning is the human digestive system.

Table 4. Comments and recommendation from media experts in learning module and learning song

\begin{tabular}{|c|c|c|}
\hline Validator & $\begin{array}{c}\text { Assessment } \\
\text { criteria }\end{array}$ & $\begin{array}{c}\text { Recommend } \\
\text { ation }\end{array}$ \\
\hline $\begin{array}{l}\text { Media Experts } \\
\text { in learning } \\
\text { module }\end{array}$ & Layout & $\begin{array}{l}\text { Setting the } \\
\text { position of } \\
\text { picture and } \\
\text { title }\end{array}$ \\
\hline $\begin{array}{l}\text { Media Experts } \\
\text { in learning } \\
\text { song }\end{array}$ & Content & $\begin{array}{l}\text { Adjusting } \\
\text { lyrics with } \\
\text { melody }\end{array}$ \\
\hline
\end{tabular}

The validation by material and media experts and composers for learning song media aims to evaluate the feasibility of the product and provide a basis for product improvement. After the validation process, the products were assessed by peers and ten students of Grade VIII Grace Anak Terang Junior High School, Salatiga. The assessment was conducted to evaluate the effectiveness of the module and learning song in improving SRL and students' cognitive learning outcome.

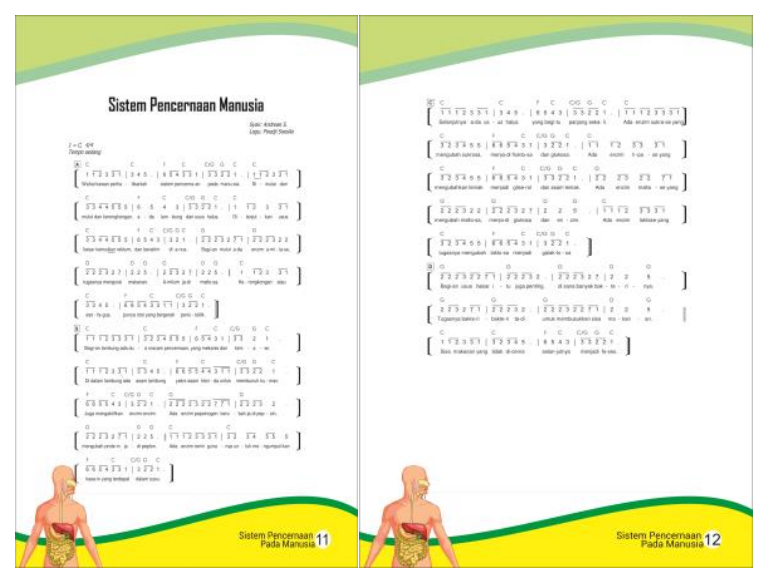

Figure 5. Learning song

Based on the results of expert validation of human digestive system material, the criteria for valid module is assessed from aspects such as the physical aspect and material accuracy (Figure 1). The physical aspect of the module is assessed from the adjustment of colors and pictures, while the accuracy is assessed based on whether the material is appropriate for 
junior high school students and whether it is up to date. In general, the media experts in learning module stated that the material is good because it meets all the criteria and it is appropriate to be used. The material experts commented on the inconsistent use of font size and recommended italics for important terms and more illustrations. In addition, the evaluation questions do not contain HOTS question type. The media experts commented on the layout between pictures and titles (Table 3 and Table 4). In general, the module has been revised in revision I stage based on the comments and recommendation from each validator. Regarding the assessment from learning song media experts, especially about the rhythm pattern of the melody, it is concluded that the score is very valid. The combination between the lyrics which contain Biology materials and the musical instruments which is adjusted with the content of the song provides students a new experience in understanding the material easily and subconsciously using a fun way (Figure 5). The composers recommended that the note and lyrics should be more adjusted with the melody (Table 4).

Therefore, in developing and producing instructional media to improve selfregulated learning and cognitive learning outcome of Grade VIII students of Grace Anak Terang Junior High School, Salatiga, module that is integrated with learning song based on flipped learning is required. The validators stated that the module that is integrated with learning song is very good and appropriate to be used to improve SRL and students' learning outcome.

The effectiveness of learning songintegrated module in improving SRL and students' cognitive learning outcome.

The purpose of conducting the limited experimental test is to determine the readability and validity of the module and learning song in conducting development research. There are two stages in the test. First, an individual assessment by two university students was conducted. It was followed by a group assessment by ten students of Grade VIII Anak Terang Junior High School, Salatiga. The university students assessed the writing aspect of the module to search for potential mistakes regarding typing, punctuation, capitalization, italics, and underlined words. Regarding the learning song, the suitability between lyrics and tones was analyzed. The average percentage of the module assessment is $84.86 \%$ (valid), while the average percentage of the learning song assessment is $77.97 \%$ (valid). The assessment results are presented in Figure 6.

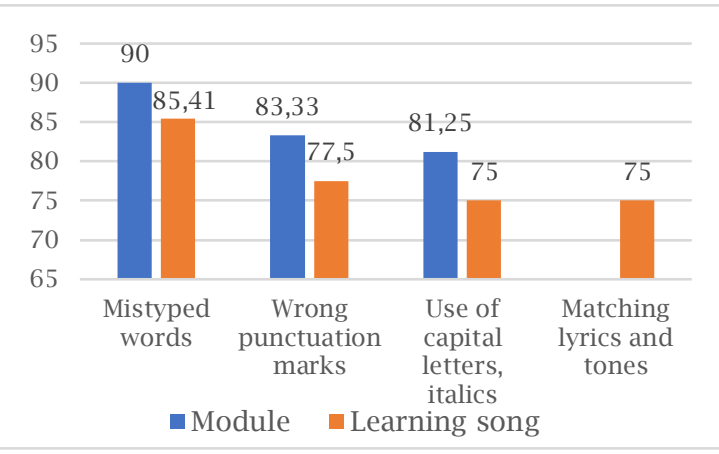

Figure 6. Module and learning song validation results by university students

The learning song-integrated module based on flipped learning was tested to teach a group of ten students from Grade VIII Anak Terang Junior High School, Salatiga. The module and learning song were employed to measure student selfregulated learning and cognitive learning outcome. The results show that the average percentage of students' learning outcome is $80.5 \%$ (good), while the achievement of SRL is $80 \%$ (good). The summary of the assessment results on the cognitive learning outcome and SRL in the limited experimental test is presented in Table 5 and Figure 7.

Table 5. Students' cognitive learning outcome

\begin{tabular}{lc}
\hline \multicolumn{1}{c}{ Aspect } & Score \\
\hline Highest Score & 100 \\
Lowest Sore & 62 \\
Standard Deviation & 15.64 \\
\hline Average & $\mathbf{8 0 . 5}$ \\
\hline
\end{tabular}

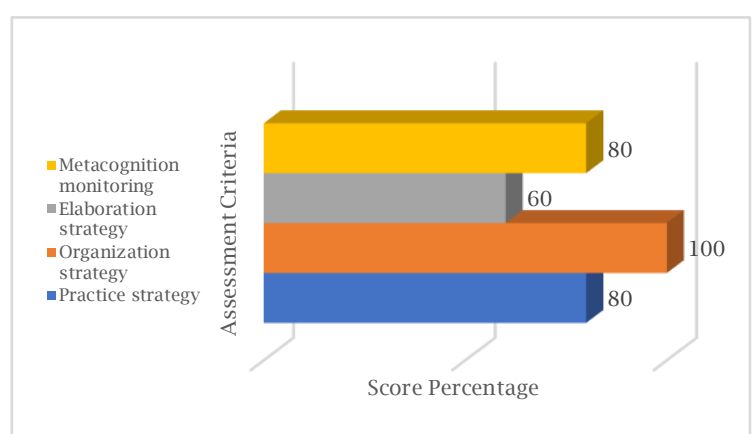

Figure 7. SRL observation based on indicators

Normality test is conducted to determine whether the sample taken from a distributed population is normal. The 
analysis technique employed in the normality test was Shapiro-Wilk using the 18.0 version of SPPS program. The data is considered normally distributed if it meets the decision criteria of Sig $>0.05$. The summary of the normality test results is illustrated in the following Table 6.

Table 6. Normality test results using ShapiroWilk

\begin{tabular}{cccc}
\hline & \multicolumn{3}{c}{ Shapiro-Wilk } \\
\hline & Statistic & Df & Sig. \\
Pre-test & 0.977 & 10 & 0.946 \\
Post-test & 0.860 & 10 & 0.077
\end{tabular}

Table 6 describes that the results of normality test for cognitive learning outcome of Grade VIII students of Anak Terang Junior High School Salatiga reached Sig. 0.946 in the pre-test and Sig. 0.077 in the post-test. It is a normal distribution because the criteria of $\mathrm{Sig}>\alpha(\alpha=0.05)$ is met. From the homogeneity test, the significance value obtained was 0.657 . It shows that Sig. $0.657>0.05$, meaning that the data come from homogenous variants.

The paired sample t-test was used to evaluate the influence of module and learning song on Self-Regulated Learning and learning outcome. The pre-test and post-test results show that the value of $t$ count was 18.295 , while the value of t table was 2.09 at the significance level of $\alpha=0.05$ with $\mathrm{df}=19$. Because $t$ count is less than $t$ table, Ho is rejected. It can be concluded that the use of learning song-integrated module based on flipped learning model has a significant effect on cognitive learning outcome and Self-Regulated Learning of Grade VIII students of Grace Anak Terang Junior High School, Salatiga regarding the human digestive system material. The summary of the paired sample t-test results can be seen in in Table 7 .

Table 7. Analysis Results of Paired Sample t-test

\begin{tabular}{lcccccc} 
& & Mean & Std. Deviation & T & df & Sig. (2-tailed) \\
\hline Pair 1 & Value - Pre_post & 7.040 & 17.20893 & 18.295 & 19 & 0.000 \\
\hline
\end{tabular}

The effectiveness test on the implementation of learning song-integrated module based on flipped learning to improve self-regulated learning showed an increase of $80 \%$ in students' self-regulated learning (Table 5). It shows that the implementation of learning song-integrated module based on flipped learning can help students improve self-management aspects. Furthermore, as stated by Lai and Hwang (2016), it can also improve student selfmanagement in controlling the mind, feeling and action to achieve the expected learning goals. The analysis shows that the students' response to the use of learning song was very good. This finding is supported by Muhsin (2012) who states that the use of learning song in learning activities can generate students' enthusiasm and interest in learning.

The ability of students to manage themselves through self-regulation activities, self-construction, monitoring, and self-reflection helps students achieve maximum learning outcome. Students who are capable of doing self-regulation in learning can explore their own potential so that they can find their own best way in learning (Kusaeri \& Mulhamah, 2016). The calculation results of self-regulated learning indicators (Figure 7) describe that the indicator which is categorized as satisfactory is elaboration. It indicates that some students are less able to keep information in a long-term memory so that they cannot achieve optimal learning outcome which is relevant with their own potential.

The analysis of Natural Science learning of Grade VIII students of Grace Anak Terang Junior High School, Salatiga indicates that the learning song-integrated module based on flipped learning generated an increase of $80.5 \%$ in the learning outcome (Table 5). It explains that the use of the module has a significant impact on students' learning outcome. In other words, the module helps students attain deeper understanding of the material. Although student learning activities depend on the student selfregulation pattern, the effectiveness of learning song-integrated module based on flipped learning in improving SRL and cognitive learning outcome was tested through normality, homogeneity and independent sample test. It can be seen from the test results that the module is proven to be effective, the research is in line with the research conducted by Love, Hodge, Grandgenett, and Swift (2014) who 
tested the effectiveness of two traditional teaching methods and flipped classroom.

In addition to the findings that have been discussed, based on the observation it was found that internal and external factors also influenced students' cognitive learning outcome. The internal factors are related to self-regulated learning. Self-regulated learning is a process of activating one's belief in gaining knowledge, motivation, and behavior to actively participate in the learning process so that they are able to focus on achieving their own learning goals. Self-regulated learning gives students a positive absorption in learning (Cheng, 2011). Febrianela (2013) also explains that there is a very significant positive relationship between SRL and students' learning outcome. The higher the SRL that the students have, the higher the academic achievement that is obtained, and vice versa.

External factors are factors that come from the outside of the students, which include the family's social environment such as parent support in the form of emotional support (love and affection, protection, attention, trust). These factors indirectly affect the students' learning outcome because they can create children's motivation in learning. The role of parents is an important component in children's education. Parents who provide support to their children in learning will be able to increase children's enthusiasm so that they can study harder with a great determination and do not give up easily when facing learning difficulties (Sucipto, 2014). The research finding provides a strong evidence of an increase in self-regulated learning and cognitive learning outcome. It can be seen from the learning achievement of Grade VIII students of Grace Anak Terang Junior High School, Salatiga which showed an excellent average score. It can be said succinctly that the entire research process has proved that the learning song-integrated module is effective in improving self-regulated learning and cognitive learning outcome of Grade VIII students of Grace Anak Terang Junior High School, Salatiga.

\section{Conclusion}

Based on the research findings and discussion, it can be concluded that the development research that has been conducted produced a learning songintegrated module that can be used as a teaching and learning media to explain about human digestive system. The learning song-integrated module produced is claimed feasible in terms of physical aspects, material coverage and accuracy, evaluation and reflection tasks. The module received a very good assessment score from media experts and students in the experimental test. The limited experimental test on students indicates that the learning song-integrated module is effective in improving self-regulated learning and cognitive learning outcome.

\section{References}

Akbar, S. (2013). Instrumen perangkat pembelajaran. Bandung: PT Remaja Rosdakarya.

Arsyad, A. (2016). Media pembelajaran (Revisi). Jakarta: Rajawali Pers.

Asyhar, R. (2012). Kreatif mengembangkan media pembelajaran. Jakarta: Gaung Persada Press.

Cheng, E. C. K. (2011). The role of selfregulated learning in enhancing learning performance. The International Journal of Research and Review, 6(1), 1-16. Retrieved from https://tijrr.webs.com/A1_ V6.1_TIJRR.pdf

Cole, J. E., \& Kritzer, J. B. (2017). Strategies for success: Teaching an online course. Rural Special Education Quarterly, 28(4), 36-40. https:// doi.org/10.1177/875687050902800 406

Enfield, J. (2013). Looking at the impact of the flipped classroom model of instruction on undergraduate multimedia students at CSUN. TechTrends, 57(6), 14-27. https://doi.org/10.1007/s11528013-0698-1

Febrianela, R. B. (2013). Self regulated learning (SRL) dengan prestasi akademik siswa akselerasi. Cognicia, 1(1). Retrieved from http:// 202.52.52.22/index.php/cognicia/ar ticle/view/1455

Febriyani, E. (2013). Pengaruh partisipasi siswa di kelas dan lingkungan sekolah terhadap prestasi belajar akuntansi siswa kelas XI IPS MAN Tempel tahun 2012/2013 (Universitas Negeri Yogyakarta). Retrieved from https://eprints. 
uny.ac.id/17830/1/Skripsi Elly Febriyani.pdf

Hamdan, N., McKnight, P., McKnight, K., \& Arfstrom, K. M. (2013). The flipped learning model: A white paper based on the literatur review titled a review of flipped learning. Retrieved from https://flippedlearning.org/wpcontent/uploads/2016/07/WhitePa per_FlippedLearning.pdf

Hanif, H. N. (2016). Perbandingan antara model pembelajaran flipped classroom berbantuan edmodo dengan pembelajaran konvensional terhadap hasil belajar sistem operasi (eksperimen kelas X SMK 1 Banyudono) (Universitas Sebelas Maret). Retrieved from https://digilib.uns.ac.id/dokumen/ detail/54537/Perbandingan-antaramodel-pembelajaran-flippedclassroom-berbantuan-edmododengan-pembelajaran-konvensionalterhadap-hasil-belajar-sistemoperasi-eksperimen-kelas-X-smk-1Banyudono

Harlen, W., \& Crick, R. D. (2003). Testing and motivation for learning. Assessment in Education: Principles, Policy \& Practice, 10(2), 169-207. https:// doi.org/10.1080/096959403200012 1270

Hui, T. hui, \& Umar, I. N. (2011). Does a combination of metaphore and pairing activity help programming performance of students with different selfregulated learning level? Turkish Online Journal of Educational Technology, 10(4), 121129. Retrieved from https://eric. ed.gov/?id=EJ946617

Ilmi, A. S. (2011). Pengaruh partisipasi siswa dalam pembelajaran terhadap prestasi belajar akuntansi siswa kelas $X-A K$ SMK Negeri 1 Tanggul pada semester genap tahun ajaran 2010/2011 (Universitas Jember). Retrieved from https:// repository.unej.ac.id/handle/12345 6789/10612

Johnson, G. B. (2013). Student perceptions of the flipped classroom (University of British Columbia). https://doi.org/ 10.1080/10511970.2015.1054011

Kusaeri, K., \& Mulhamah, U. N. (2016). Kemampuan regulasi diri siswa dan dampaknya terhadap prestasi belajar matematika. Jurnal Review Pembelajaran Matematika, 1(1), 3142. https://doi.org/10.15642/jrpm. 2016.1.1.31-42

Lai, C.-L., \& Hwang, G.-J. (2016). A selfregulated flipped classroom approach to improving students' learning performance in a mathematics course. Computers \& Education, 100, 126-140. https://doi.org/10.1016/j.compedu. 2016.05.006

Love, B., Hodge, A., Grandgenett, N., \& Swift, A. W. (2014). Student learning and perceptions in a flipped linear algebra course. International Journal of Mathematical Education in Science and Technology, 45(3), 317-324. https://doi.org/10.1080/0020739X. 2013.822582

Mardapi, D. (2008). Teknik penyusun instrumen tes dan non tes. Yogyakarta: Mitra Cendekia.

Markova, A. K. (2014). Ways of investigating motivation for learning in schoolchildren. Soviet Psychology, 28(6), 21-42. https://doi.org/ 10.2753/RPO1061-0405280621

Muhsin, M. A. (2012). Pembelajaran media songs based learning siswa kelas VII SMP Negeri 1 Sinjai Borong Kabupaten Sinjai. Jurnal Media, 1(2), 111-129. Retrieved from https:// www.researchgate.net/profile/muh_ arief_muhsin/publication/3100608 58_pembelajaran_media_songs_bas e_learning_siswa_kelas_vii_smp_neg eri_1_sinjai_borongkabupaten_sinja i/links/58287cce08ae5c0137f0f9f2 /pembelajaran-media-songs-baselearning-siswa-kelas

Munafifah, E. (2016). Pembelajaran think pair share dengan kesimpulan learning song sebagai upaya meningkatkan kemampuan berfikir dan berkomunikasi serta membuat suasana menyenangkan siswa MTsN Blitar pada pokok bahasan suhu. Jurnal Penelitian Pendidikan IPA, 1(1), 27-32. https://doi.org/ 10.26740/jppipa.v1n1.p27-32

Nasution, Y. A., Hasruddin, H., \& Gultom, T. (2018). Pengembangan lembar kerja mahasiswa (LKM) berbasis inkuiri kontekstual materi mikrobiologi air pada mahasiswa pendidikan biologi. 
Edusains, 10(1), 113-119. https:// doi.org/10.15408/es.v10il.8124

Oliveira, P. C., \& Oliveira, C. G. (2013). Using conceptual questions to promote motivation and learning in physics lectures. European Journal of Engineering Education, 38(4), 417$424 . \quad$ https://doi.org/10.1080/ 03043797.2013.780013

Paas, F., Renkl, A., \& Sweller, J. (2003). Cognitive load theory and instructional design: Recent developments. Educational Psychologist, 38(1), 1-4. https://doi.org/10.1207/S15326985 EP3801_1

Schellenberg, E. G. (2006). Long-term positive associations between music lessons and IQ. Journal of Educational Psychology, 98(2), 457468. https://doi.org/10.1037/00220663.98.2.457

Septiani, A., Syakbaniah, S., \& Mufit, F. (2013). Pengembangan bahan ajar CD interaktif materi suhu dan kalor berbentuk powerpoint materi suhu dan kalor untuk pembelajaran fisika kelas X SMA. Pillar of Physics Education, 2, 49-56. Retrieved from http://ejournal.unp.ac.id/students/i ndex.php/pfis/article/view/729

Sinaga, K. (2017). Penerapan flipped classroom pada mata kuliah kimia dasar untuk meningkatkan selfregulated learning belajar mahasiswa. Jurnal Inovasi Pendidikan Kimia, 11(2), 1932-1944. Retrieved from https://journal. unnes.ac.id/nju/index.php/JIPK/art icle/view/10609/6475

Smith, J. D. (2013). Student attitudes toward flipping the general chemistry classroom. Chem. Educ. Res. Pract.,
14(4), 607-614. https://doi.org/ 10.1039/C3RP00083D

Song, Y., Jong, M. S. Y., Chang, M., \& Chen, W. (2017). Guest editorial: "How" to design, implement and evaluate the flipped classroom? - A synthesis. Journal of Educational Technology \& Society, 20(1), 180-183. Retrieved from https://www.jstor.org/stable /10.2307/jeductechsoci.20.1.180

Sucipto, S. (2014). Pengaruh self-regulated learning dan dukungan orang tua terhadap hasil belajar peserta didik pada mata pelajaran ekonomi program studi IPS SMA Negeri di Kota Jombang. Jurnal Ekonomi Pendidikan Dan Kewirausahaan, 2(2), 236-250. https://doi.org/10. 26740/jepk.v2n2.p236-250

Wolters, C. A., Pintrich, P. R., \& Karabenick, S. A. (2005). Assessing Academic Self-Regulated Learning. In K. A. Moore \& L. H. Lippman (Eds.), What Do Children Need to Flourish? (pp. 251-270). https://doi.org/10.1007/ 0-387-23823-9_16

Zhang, H., Du, X., Yuan, X., \& Zhang, L. (2016). The effectiveness of the flipped classroom mode on the english pronunciation course. Creative Education, 07(09), 13401346. https://doi.org/10.4236/ ce.2016.79139

Zheng, L., Li, X., \& Chen, F. (2016). Effects of a mobile self-regulated learning approach on students' learning achievements and self-regulated learning skills. Innovations in Education and Teaching International, 55(6), 616-624. https://doi.org/10.1080/14703297. 2016.1259080 